\title{
Benefits of interventions for respiratory secretion management in adult palliative care patients - a systematic review
}

\author{
Juliano Ferreira Arcuri ${ }^{1 *}$, Ebun Abarshi ${ }^{2}$, Nancy J. Preston ${ }^{2}$, Jenny Brine ${ }^{3}$ and Valéria Amorim Pires Di Lorenzo
}

\begin{abstract}
Background: Respiratory secretions impact negatively on palliative patients. Unfortunately, a gold standard therapy is not yet available. The purpose of this study was to identify which interventions are in use to control respiratory secretions in patients with chronic disease with a poor prognosis and verify their effects on outcomes relevant for palliative care patients.

Methods: A systematic review of the literature with narrative summary was conducted. We searched eight electronic databases in April ${ }^{6 \text { th }}, 2016$. Citation-tracking and reference list searches were conducted. We included randomized controlled trials, crossover trials, observational and qualitative studies regarding interventions for respiratory secretion management in adult patients with chronic diseases that met inclusion criteria indicating short prognosis.

Results: Six randomized controlled trials, 11 observational studies, ten crossover trials and one qualitative study were found. Interventions included mechanical insufflation-exsufflation (MIE), expiratory muscle training, manuallyassisted cough, tracheotomy, chest physiotherapy, suctioning, air stacking, electrical stimulation of abdominal muscles, nebulized saline, positive expiratory pressure masks, percussive ventilation, high frequency chest wall oscillations. The interventions with most promising benefits to patients in palliative care were manually-assisted cough and mechanical insufflation-exsufflation to promote expectoration and percussive ventilation to improve mucous clearance.
\end{abstract}

Conclusion: Therapies, such as manually assisted cough, mechanical insufflation-exsufflation and percussive ventilation, which aim to deal with respiratory secretion, were the most promising treatment for use in palliative care for specific diseases. Nevertheless, the evidence still needs to improve in order to identify which treatment is the best.

Keywords: Respiratory secretion, Palliative Care, Cough, Sputum

\section{Background}

The presence of mucus within and around the respiratory tract towards the end-of-life can be burdensome, for patients already facing death for a number of reasons. Continuous accumulation of mucus tends to negatively impact the quality of life and the dying process and leads to social isolation as excessive expectoration may be disturbing to some people and cultures [1]. However research around the benefits of interventions

\footnotetext{
* Correspondence: julianoarcuri@gmail.com

'Federal University of São Carlos, Rod Washington Luiz, km 235, Monjolinho, São Carlos, SP CEP 13565-905, Brazil

Full list of author information is available at the end of the article
}

used to manage this symptom is somewhat scarce. Problems in dealing with respiratory secretions are caused by increased production of airway secretions or inefficient elimination of the mucus or both and as a result, mucus encumbrance is difficult to control.

The increased production of respiratory mucus is common in patients with cardiorespiratory [2] diseases and lung, head and neck cancer. Sometimes these conditions are associated with cough inefficiency due to muscle weakness and poor coordination [3, 4]. However, other diseases may cause this discomfort only due to a deficiency in mucus elimination caused by cough inefficiency such as in neurologic diseases [1,5-7]. Most of 
the diseases associated with the presence of respiratory secretion are chronic conditions and they may be lifethreatening in their later stages, which is an indication for palliative care.

As a consequence to patients, an augmented amount of secretion is associated with an increase in dyspnoea, cough and the chances of respiratory complications, such as pneumonia. Furthermore, there is an associated poor prognosis in chronic obstructive pulmonary disease (COPD) patients $[3,4]$ and secretions may interfere in the efficacy of other interventions, such as non-invasive ventilation. Unfortunately, a gold standard therapy is not yet available.

The interventions to help patients deal with respiratory secretion have different goals and the choice must depend on the patient's condition. Three main goals are: (1) promote expectoration; (2) increase mucociliary clearance and conduct of the secretions to the upper airways; (3) improve cough effectiveness.

Some therapies that are suitable to treat patients with reversible conditions that are facing difficulties in dealing with respiratory secretion, might not be suitable in patients in palliative care. Suctioning is one such therapy indicated to remove respiratory secretion from patient's airways, however, it is uncomfortable and associated with complications, such as pain, uncontrollable coughing, infection, atelectasis, hypoxemia, haemoptysis and airway injuries [8]. In addition, palliative care guidelines suggest that the indication of suctioning procedure should be done with caution, since it is a painful procedure $[9,10]$.

Other pharmacological and non-pharmacological interventions have been clinically used to control respiratory secretion and examples are mucolitics [11], antibiotics [3] and respiratory physiotherapy $[1,12]$. Systematic reviews $[11,13]$ have shown that mucolitics and respiratory physiotherapy have been successfully used in the management of this symptom in patients with COPD, but not specifically in the end stages.

However, there is no clear evidence on whether the available interventions would be effective and suitable for patients receiving palliative care, since patients facing life-threatening diseases have specific treatment goals, which are not always verified in studies with patients with less severity.

\section{Research question}

What are the benefits of pharmacological and/or nonpharmacological interventions in adult palliative care patients that are facing problems in dealing with respiratory secretion?

\section{Objective}

The objective of this study was to identify which interventions are in use to control respiratory secretion in patients with chronic disease with a poor prognosis and verify their effects on outcomes relevant for palliative care.

\section{Methods}

\section{Search strategy and data extraction}

The literature search was conducted in September 23th of 2014, and updated in April $6^{\text {th }}$ of 2016. The review process involved:

1) A literature search was performed to retrieve journal articles and grey literature using the search strategy (Additional file 1). Thereafter, the results were imported to the reference software ENDNOTE $\mathrm{X}^{\circ}$ (Thomson Reuters, New York, NY) (JB) 2).2) An initial selection based on titles was performed by two independent reviewers (JFA and JB) and possible disagreements were resolved by a third reviewer (VAPDL). Studies were excluded when they were duplicates or clearly did not meet the inclusion criteria (Table 1) 3) The abstracts of these studies were read and retained where the content was relevant to the topic under consideration (JFA and JB) with disagreements resolved by a third reviewer (VAPDL) 4) The full papers were read by two independent reviewers (JFA and EA) to verify the inclusion criteria 5) A citation track and a reference search of included studies was performed (JB) 6) Data extraction was performed by two independent reviewers (JFA and EA) 7) The assessment of the methodological quality of the studies was done by two independent reviewers (JFA and VAPDL) using the PEDro scale, a 11-item scale, which ten are included in

Table 1 Inclusion criteria

\begin{tabular}{|c|c|}
\hline Inclusion & Exclusion \\
\hline $\begin{array}{l}\text { Was the population studied with the severity of the chronic disease } \\
\text { identifiable and with one of the National Hospice Organization Criteria? [15] }\end{array}$ & $\begin{array}{l}\text { Did the study involve a population with disease severity that is not } \\
\text { identifiable, or without any of the National Hospice Organization Criteria? [15] }\end{array}$ \\
\hline $\begin{array}{l}\text { Were the interventions performed to treat cough ineffectiveness, } \\
\text { respiratory hypersecretion or its consequences (relative distress)? }\end{array}$ & Were the interventions focused in treating other symptoms? \\
\hline Was the study composed in its majority of adults? & Did the study involve animals? \\
\hline $\begin{array}{l}\text { Was it a randomized clinical trial, observational study or a qualitative } \\
\text { study? }\end{array}$ & Was the study about death rattle? \\
\hline
\end{tabular}


the total score, in which higher scores represent better methodological quality $[14,15]$. Lastly, the evidence was summarized using the Oxford Centre for Evidence-based Medicine (OCEBM) levels of evidence 2011, this score considered the level of evidence as (1) systematic reviews of randomized controlled trials; (2) Randomized controlled trials or observational studies with dramatic effect; (3) Non-randomized trials/follow-up studies; (4) case series, case-control studies or historically controlled studies and (5) Mechanism-based reasoning [16]. The level is recorded in brackets against the studies.

Ethics approval was not requested since this study did not involve humans, human data or animals.

\section{Electronic search}

The following databases were searched: AMED, British Nursing Index, CINAHL, EMBASE, LILACS (for South American publications), PEDro, MedLine, Web of Science. The search carried out in MedLine is set out in the table in the Additional file 1 and was adapted for use in other databases.

\section{Grey literature}

Searches were carried out in clinical trials registers, including the Cochrane Airways Group Specialised Register of trials, thesis and dissertations databases, NICE Evidence, GoogleScholar (JB). The studies retrieved were evaluated by two different reviewers (JFA and NP) and any disagreement was resolved by a third reviewer (VAPDL).

\section{Outcomes}

The primary outcomes of the review were subjective impression on effectiveness of the intervention and comfort during therapy. Moreover, all outcomes used to assess the therapies in the studies were included. The outcomes were presented as mean \pm standard deviation or median (interquartile range 25-75\%). Based in their opinion, authors classified the outcomes as critically relevant, relevant or less relevant for clinical decision in palliative care.

\section{Results}

The search was conducted in September 2014 and updated in April 2016. 5413 papers were identified by the search which resulted in 28 studies included in the review, a study flowchart is on Fig. 1. These included six randomized controlled trials [17-22] (Table 2), ten cross-over trials [23-32] (Table 3), 11 observational studies [33-43] and one qualitative study [44]. Associated conditions were multiple sclerosis [18, 21, 36], neuromuscular disorders [19, 22-29, 31, 33-36, 38-44], spinal cord injury [17, 30, 35, 37], COPD [20, 24] and cystic fibrosis [32]. Interventions were mechanical insufflation-exsufflation (MIE) [17, 22-29, 33-44], manually assisted cough (MAC) [23, 25, 28, 29, 31], expiratory muscle training (EMT) $[18,21]$, percussive ventilation [31], positive expiratory pressure (PEP) masks associated [32] or not [20] to hypertonic saline nebulisation, abdominal muscles electrical stimulation [30] and vibratory vest [19] (Table 4). Other interventions were mentioned in the studies which were represented as usual care but, since they were used alongside other interventions, they lacked results for evidence summarization.

The randomized controlled trials and cross-over trials had their methodological quality assessed by PEDro Scale. The highest score (6 points) was achieved by Chaisson et al randomized controlled trial, while the lowest score (1 point) was achieved by Pillastrini et al. [17] Only one study [19] achieved more than a half of the criteria. Five of the six randomized controlled trials did not conceal the random allocation, none were blinded, and one was analysed in intention to treat. Furthermore, only $50 \%$ of the cross-over trials were randomized, none had a concealed allocation, and only one was blinded to the assessors [27]. Although the sample size is not assessed by PEDro scale, three randomized controlled trials do not present power calculation $[17,19,21]$. The scores in PEDro scale are in Tables 2 and 3, and a detailed table is available in the Additional file 1 Table S2 and Table S3).

\section{Therapies to promote expectoration}

Three therapies were found to help promoting expectoration (Table 4): MAC, tracheotomy (to facilitate suctioning procedures) and MIE. MAC and tracheotomy are usual procedures in patients with cough inefficiency. However, MIE equipment is not usual in general hospitals, but is relatively common in neuromuscular disease care centres.

MAC is a technique which increases peak cough flow by manual thrust in the abdominal wall conducted by a therapist or carer that can be optimized using some sort of inspiratory aid, such as a resuscitation bag or mechanical ventilation [23]. It is a simple and relatively costfree intervention and should be the first line therapy in cough inefficiency. Nevertheless, patients must have a minimum level of cooperation; otherwise they would not cough with the manual thrust [45] and in very severe patients, it might cause fatigue. Moreover, abdominal thrust may cause pain in some cancer patients.

MAC (Tables 2 and 3) was considered more comfortable than other techniques (level 3) [23] and led to an increase in maximum expiratory pressure (PEMax) (level 3) [30] and peak cough flow (PCF) (level 2) [23, 25, 29] and in two studies, the increase was high enough to achieve a level of PCF $(>270 \mathrm{~L} / \mathrm{min})$ considered to be effective [23, 29]. In addition, effectiveness was confirmed by the patient's subjective impression (level 3) [23, 29]. 


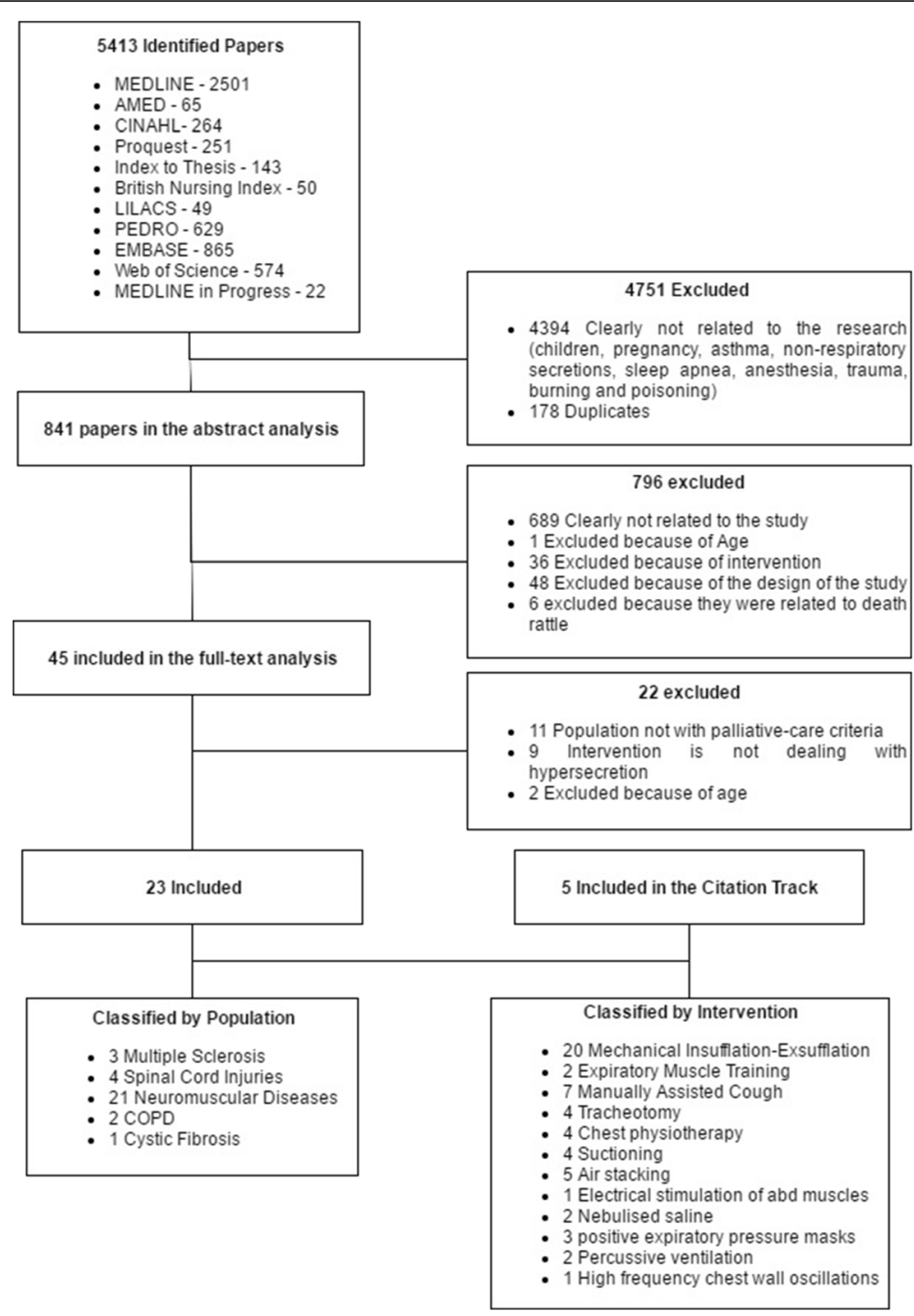

Fig. 1 PRISMA Flowchart

However, one study presented contradictory results [28] for PCF, comfort and effectiveness. This study used a non-invasive mechanical ventilator for inspiratory assistance and pressure was adjusted according to patient comfort, while the studies with better outcomes used the highest tolerable pressure or $40 \mathrm{cmH}_{2} \mathrm{O}$ [29] or air stacking using a resuscitation bag $[23,25]$. This contradiction suggests that the inspiratory aid should always be the maximum tolerated or $40 \mathrm{cmH}_{2} \mathrm{O}$. This finding is corroborated by Senent and colleagues [23] who tested both inspiratory aid of $30 \mathrm{cmH}_{2} \mathrm{O}$ and resuscitation bag and found that the former was not as effective as the latter.

Another intervention was tracheotomy, which is a common procedure and associated with mechanical ventilation which can increase survival (level 2) in patients with cough insufficiency (amyotrophic lateral sclerosis and Duchenne dystrophy) $[39,40]$, since it facilitates and makes suctioning and ventilatory assistance more tolerable. However, a surgical procedure is not usually the choice in patients in palliative care, unless there is no other non-invasive alternative. Moreover, tracheotomy might impair speaking resulting in lower social interaction and swallowing (the tube weight decreases the movements of the trachea, which changes the dynamics of swallowing), which might not be compensated by the gain in survival time.

The therapy with the most included studies was MIE (Tables 2 and 3), where a patient receives a positive pressure, by a mask or tracheotomy, to inflate the lungs, followed by a negative pressure to promote expectoration. Twenty one studies assessed MIE (two randomized controlled trial, one qualitative study, seven cross-over trials and 11 observational studies). A cross-over trial verified 
Table 2 Randomized clinical trials

\begin{tabular}{|c|c|c|c|}
\hline Population\PEDro Scale & Groups & Intervention & Outcomes \\
\hline \multirow{2}{*}{$\begin{array}{l}\text { Pillastrini et al (2006) [17] } \\
\text { Upper Spinal Cord Injury } \\
1\end{array}$} & Control $(n=4)$ & Chest Physiotherapy & No improvement: $\mathrm{FVC} ; \mathrm{FEV}_{1} ; \mathrm{PCF} ; \mathrm{FEV}_{1} / \mathrm{FVC} ; \mathrm{PaO}_{2} ; \mathrm{PaCO}_{2} ; \mathrm{Ph} ; \mathrm{SaO}_{2}$ \\
\hline & $\begin{array}{l}\text { Experimental } \\
(n=5)\end{array}$ & Chest Physiotherapy + MIE & $\begin{array}{l}\text { Improvement: FVC } \mathrm{F}^{\mathrm{a}} \text { (Before } 0.37 \pm 0.23 \mathrm{ml} / \mathrm{After} 0.46 \pm 0.21 ; \uparrow 24 \% \text { ); } \mathrm{FEV}_{1}^{\mathrm{a}} \\
\text { (Before } 0.21 \pm 0.15 \mathrm{ml} / \mathrm{After} 0.28 \pm 0.14 ; \uparrow 33 \% \text { ); } \mathrm{PCF}^{\mathrm{a}} \text { (Before } 0.24 \pm 0.19 \mathrm{~L} / \mathrm{s} \\
\text { /After } 0.31 \pm 0.19 \mathrm{~L} / \mathrm{s} ; \uparrow 29 \% \text { ). } \\
\text { No improvement: } \mathrm{FEV}_{1} / \mathrm{FVC} ; \mathrm{PaO}_{2} ; \mathrm{PaCO}_{2} ; \mathrm{Ph}^{2} \mathrm{SaO}_{2} .\end{array}$ \\
\hline \multirow{2}{*}{$\begin{array}{l}\text { Gosselink et al (2000) [18] } \\
\text { Multiple Sclerosis } \\
5\end{array}$} & Control $(n=9)$ & $\begin{array}{l}\text { Non-supervised breathing } \\
\text { exercises }\end{array}$ & No Improvement: PIMax; Pulmonary Index, FVC; PEMax. \\
\hline & Training $(n=9)$ & $\begin{array}{l}\text { Expiratory muscle training } \\
\text { (Threshold) }\end{array}$ & $\begin{array}{l}\text { Improvement : PIMax }{ }^{\mathrm{a}}\left(\uparrow 39 \pm 41 \mathrm{cmH}_{2} \mathrm{O}\right) \text {; Pulmonary Index }{ }^{\mathrm{b}}(\downarrow 2 \pm 1 \mathrm{pts}) \text {. } \\
\text { No Improvement: FVC; PEMax. }\end{array}$ \\
\hline \multirow{2}{*}{$\begin{array}{l}\text { Chaisson et al (2006) [19] } \\
\text { ALS } \\
6\end{array}$} & Control $(n=4)$ & Manually assisted cough & $\begin{array}{l}\text { No improvement: Respiratory complications; Rate of decline in FVC; } \\
\text { Survival days. }\end{array}$ \\
\hline & $\begin{array}{l}\text { Experimental } \\
(n=5)\end{array}$ & $\begin{array}{l}\text { Manually assisted } \\
\text { cough + Vibratory vest }\end{array}$ & $\begin{array}{l}\text { No improvement: Respiratory complications; Rate of decline in FVC; } \\
\text { Survival days. }\end{array}$ \\
\hline \multirow[t]{2}{*}{$\begin{array}{l}\text { Christensen et al (1990) } \\
{[20]} \\
\text { COPD } \\
4\end{array}$} & Control $(n=22)$ & $\begin{array}{l}\text { SHAM therapy with } \\
\text { low PEP mask }\end{array}$ & $\begin{array}{l}\text { No improvement: } \mathrm{FEV}_{1} ; \mathrm{FVC} ; \mathrm{PaO}_{2} ; \mathrm{PaCO}_{2} ; \text { dyspnoea during activities; } \\
\text { cough; sputum; exacerbations; bedridden days; hospitalizations and } \\
\text { days with antibiotics. }\end{array}$ \\
\hline & $\begin{array}{l}\text { Experimental } \\
(n=25)\end{array}$ & Therapy with PEP mask & $\begin{array}{l}\text { No Improvement: } \mathrm{FEV}_{1} ; \mathrm{FVC} \mathrm{PaO}_{2} \text {; dyspnoea walking on ground level; } \\
\text { sputum; exacerbations; bedridden days; hospitalizations and days with } \\
\text { antibiotics. } \\
\text { Worsening: Cough }{ }^{\mathrm{b}}[\downarrow 11(-69-75) \mathrm{mm}] ; \mathrm{PaCO}_{2}\left[\uparrow 0.05(-69-75) \mathrm{kPa}^{\mathrm{b}} \text {; }\right. \\
\text { dyspnoea walking on staircase }{ }^{\mathrm{b}}[\downarrow 1(-69-53) \mathrm{mm}]\end{array}$ \\
\hline \multirow{2}{*}{$\begin{array}{l}\text { Smeltzer et al (1996) [21] } \\
\text { Multiple Sclerosis } \\
4\end{array}$} & Control $(n=5)$ & $\begin{array}{l}\text { SHAM therapy with } \\
\text { Threshold }\end{array}$ & No improvement: PIMax; PEMax. \\
\hline & $\begin{array}{l}\text { Experimental } \\
(n=10)\end{array}$ & $\begin{array}{l}\text { Expiratory muscle training } \\
\text { (Threshold) }\end{array}$ & $\begin{array}{l}\text { Improvement: PEMax }{ }^{\mathrm{b}}\left(19,4 \pm 9.9 \mathrm{cmH}_{2} \mathrm{O} ; \uparrow 19 \%\right) \text {. } \\
\text { No improvement: PIMax. }\end{array}$ \\
\hline \multirow{2}{*}{$\begin{array}{l}\text { Rafiq et all (2015) [22] } \\
\text { NMD } \\
5\end{array}$} & $\begin{array}{l}\text { Breath Stacking } \\
(n=21)\end{array}$ & Breath Stacking Therapy & $\begin{array}{l}\text { No improvement: Hospital Admissions, number of antibiotics days, } \\
\text { pulmonary morbidities, Survival, quality of life. }\end{array}$ \\
\hline & MIE $(n=19)$ & MIE & $\begin{array}{l}\text { No Improvement: Hospital Admissions, number of antibiotics days, Hospital } \\
\text { Admissions, number of antibiotics days, pulmonary morbidities, Survival, } \\
\text { quality of life. }\end{array}$ \\
\hline
\end{tabular}

Values presented as mean \pm standard deviation or median (interquartile range). ${ }^{a}$ pre-post intra-group comparison; ${ }^{b}$ statistical difference between groups; $F V C$

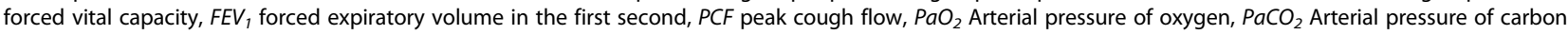
dioxide, $\mathrm{SaO}_{2}$ Arterial Oxygen Saturation, MIE Mechanical Insufflation-Exsufflation, PIMax Maximum inspiratory pressure, PEMax Maximum expiratory pressure, COPD Chronic obstructive pulmonary disease, PEP Positive expiratory pressure, ALS Amyotrophic lateral sclerosis, NMD Neuromuscular Disease

the effect of this therapy in COPD and neuromuscular diseases [24]; one verified its effects in a group of patients with respiratory failure with different illnesses [35], all the other studies included patients with neurological [17, 37], neuromuscular [22, 23, 26, 27, 29,33,34,36, 38-44], or both diseases $[25,28]$.

MIE is a promising therapy to promote expectoration in palliative care. Firstly, it is more comfortable than suctioning (level 3), but this was only studied in tracheotomised patients [26] and comfort might be even better in comparison with nasotracheal suctioning with MIE by a mask which future studies need to confirm. In addition, the use of MIE associated with non-invasive ventilation may prevent, delay or allow the removal tracheotomy in patients with NMD (level 2) [33, 35, 43], decrease respiratory complications [42] and hospitalizations [36]. A study [22] verified no changes in hospitalization, antibiotics days, pulmonary moridities using MIE when compared to cough assisted by breathing stacking technique. However, this study had more severe patients included in MIE group when compared to breath stacking group, which may have influenced the results.

Secondly, according to patients' subjective assessments, MIE was more effective than suctioning (level 3) [26] and, when associated to MAC, MIE was more effective than MAC alone [23, 29]. In a randomized controlled trial, Pillastrini and colleagues [17] verified an increase in PCF which corroborates the effectiveness findings. Moreover, increase in PCF values was verified by other studies and a systematic review, and it increased above $270 \mathrm{~L} / \mathrm{min}$ (level 1) [23, 25, 29, 46]. Furthermore, MIE improves oxygenation in COPD and NMD patients [24].

Thirdly, MIE is a therapy that can be conducted by family carers and it brought the feeling that they were able to do something for the patient (level 4) [44]. It may be one of the factors why MIE along with other non-invasive ventilation approaches reduced the number of patients with Duchenne Dystrophy that were living in a rehabilitation hospital [42]. Nevertheless, MIE is contra-indicated when 
Table 3 Cross-over trials

\begin{tabular}{|c|c|c|c|c|}
\hline Population/PEDro Scale & Interventions & \multicolumn{3}{|l|}{ Outcomes } \\
\hline Senent et al (2011) [23] & $\begin{array}{l}\text { Coached unassisted } \\
\text { cough }\end{array}$ & \multicolumn{3}{|l|}{ No improvements } \\
\hline \multirow{6}{*}{$\begin{array}{l}\text { Neuromuscular } \\
\text { diseases }(n=16) \\
3\end{array}$} & $\begin{array}{l}\text { Couched unassisted } \\
\text { cough }+ \text { abdominal thrust }\end{array}$ & \multicolumn{3}{|l|}{ No improvements } \\
\hline & $\begin{array}{l}\text { Abdominal thrust + Air } \\
\text { Stacking }\end{array}$ & \multicolumn{3}{|c|}{$\begin{array}{l}\text { Improvements: PCF:284(146-353)L/min, } \uparrow 238 \% \text { than baseline } 84(35-118) L / m i n \\
\text { (statistically higher than first two methods) }\end{array}$} \\
\hline & $\begin{array}{l}\text { Abdominal thrust + usual patient's } \\
\text { bi-level ventilator }\end{array}$ & \multicolumn{3}{|c|}{$\begin{array}{l}\text { Improvements: PCF:212(99-595)L/min, } \uparrow 152 \% \text { than baseline (statistically higher } \\
\text { than first two methods)/Comfort (VAS): } 8(7-8) \text { pts, } \uparrow 60 \% \text { than baseline } 5(4-7) \text { pts } \\
\text { (statistically higher than all other methods). }\end{array}$} \\
\hline & $\begin{array}{l}\text { Abdominal thrust + IPAP } \\
\text { of }+30 \mathrm{~cm} \mathrm{H}_{2} \mathrm{O}\end{array}$ & \multicolumn{3}{|c|}{$\begin{array}{l}\text { Improvements: PCF: } 233(100-389) L / m i n, ~ \uparrow 177 \% \text { than baseline (statistically higher } \\
\text { than first two methods). }\end{array}$} \\
\hline & MIE $\left(40 \mathrm{cmH}_{2} \mathrm{O}\right)$ & \multicolumn{3}{|c|}{$\begin{array}{l}\text { Improvements: PCF: } 488(243-605) L / \text { min ( } \uparrow 480 \%) \text { than baseline/Effectiveness } \\
\text { (VAS): } 8(6-8) \text { pts } \uparrow 100 \% \text { than baseline } 4(2-7) \text { pts (statistically higher than all } \\
\text { other methods). }\end{array}$} \\
\hline & & $\operatorname{NMD}(n=7)$ & $\operatorname{ALS}(n=13)$ & $\operatorname{COPD}(n=9)$ \\
\hline \multirow{3}{*}{$\begin{array}{l}\text { Winck et al (2004) }[24] \\
\text { Neuromuscular Disease } \\
\text { and COPD }(n=29) \\
3\end{array}$} & $\operatorname{MIE}\left(15 \mathrm{cmH}_{2} \mathrm{O}\right)$ & No Improvements & No Improvements & No Improvements \\
\hline & $\operatorname{MIE}\left(30 \mathrm{cmH}_{2} \mathrm{O}\right)$ & No Improvements & No Improvements & No Improvements \\
\hline & $\operatorname{MIE}\left(40 \mathrm{cmH}_{2} \mathrm{O}\right)$ & $\begin{array}{l}\text { Improvements: PCF: } \\
220(190-300) L / m i n, \\
\uparrow 22 \% \text { than baseline } 180 \\
(150-275) \text { L/min/SpO } \\
94(92-96) \text {, than 98(97-98), } \\
\uparrow 4 \% / D y s p n o e a \text { (BORG) } 0.75 \\
\text { (0-2.3)pts, } \downarrow 62 \% \text { than baseline } \\
\text { 2(0.4-3.3)pts. }\end{array}$ & $\begin{array}{l}\text { Improvements:PCF:200 } \\
(170-352) \mathrm{L} / \mathrm{min} \uparrow 17 \% \text { than } \\
\text { baseline } 170(128-300) \mathrm{L} / \mathrm{min} / \\
\mathrm{SpO}_{2}: 98(97-98) \%, \uparrow 4 \% \text { than } \\
\text { baseline } 94(94-95) \%\end{array}$ & $\begin{array}{l}\text { Improvements: } \mathrm{SpO}_{2} \text { : } \\
97(95-97) \%, \uparrow 5 \% / \\
\text { than baseline } 92 \\
(91-94) \% \text {, Dyspnoea } \\
\text { (BORG) 1(1-2.5)pts, } \\
\downarrow 200 \% \text { than } \\
\text { baseline 3(2-4)pts. }\end{array}$ \\
\hline
\end{tabular}

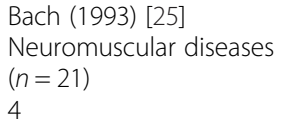

Linder (1993) [30]

\section{Air Stacking}

Manually Assisted Cough

MIE (Individualized pressure)

Tracheal Suctioning

MIE $\left(40 \mathrm{cmH}_{2} \mathrm{O}\right)$

Interventions

Chest

Physiotherapy + MIE

Standard Physiotherapy

Assisted Cough

Cough + Non-Invasive

Ventilation

Exsufflation Assisted Cough

MIE

MIE (highest tolerable pressure)

MAC + IPAP

MAC + MIE (highest tolerable pressure)

Cough with FES

MAC
Improvements: PCF: $3.37 \pm 1.07 \mathrm{~L} / \mathrm{s}, \uparrow 86 \%$ than baseline $1.81 \pm 1.03 \mathrm{~L} / \mathrm{s}$

Improvements: PCF: $4.27 \pm 1.29 \mathrm{~L} / \mathrm{s}, \uparrow 135 \%$ than baseline

Improvements PCF: $7.47 \pm 1.02 \mathrm{~L} / \mathrm{s}, \uparrow 312 \%$ than baseline (higher than all other methods)/FVC: $0.54 \pm 0.39 \mathrm{~L}, \uparrow 10 \%$ than baseline $0.49 \pm 0.37 \mathrm{~L} / \mathrm{FEF} 25-75 \%$ : $0.91 \pm 0.69 \mathrm{~L} / \mathrm{s}, \uparrow 13 \%$ than baseline $0.80 \pm 0.59 \mathrm{~L} / \mathrm{s}$

Improvements: WB: $0.95 \pm 0.23 \mathrm{~J} / \mathrm{L}, \downarrow 7 \%$ than baseline $1.03 \pm 0.25 \mathrm{~J} / \mathrm{L}$ Worsening: All patients referred as less comfortable and effective than MIE

Improvements: $\mathrm{SpO}_{2}: \uparrow 3 \%$ than baseline $93.5 \pm 2.25 \% /$ Peak Inspiratory Pressure: $15.33 \pm 4.13 \mathrm{cmH}_{2} \mathrm{O}, \downarrow 17 \%$ than baseline $18.5 \pm 4.23 \mathrm{cmH}_{2} \mathrm{O} /$ Mean Airway Pressure: $3.83 \pm 1.72 \mathrm{cmH}_{2} \mathrm{O}, \downarrow 8 \%$ than baseline $4.67 \pm 1.37 \mathrm{cmH}_{2} \mathrm{O} / \mathrm{WB}: 0.87 \pm 0.26, \downarrow 15 \%$ than baseline

Outcomes

Improvements: $\downarrow$ Duration of the intervention (17 min shorter than only Physiotherapy)

No improvements

No improvements

Improvements: PCF $\uparrow^{a}$

Improvements: PCF $\uparrow^{a}$

Improvements: PCF $\uparrow^{a}$ than baseline; Effective Cough Time $\uparrow^{a}$ compared to baseline Improvements: Effectiveness: 8.3(7.2-9)pts, $\uparrow 29.6 \%$ than MIE 6.4(4.8-8.2)pts; PCF $\uparrow^{a}$; Effective Cough Time $\uparrow^{\text {a }}$ (all compared to MIE)

Improvements: Effectiveness: 8.5(6.2-9)pts, $\uparrow 32.8 \%$ higher than MIE; PCF $\uparrow^{\text {a }}$; Effective Cough Time $\uparrow^{a}$ (all compared to MIE)

Improvements: PEMax: $60 \pm 22.8 \mathrm{cmH}_{2} \mathrm{O}, \uparrow 119,7 \%$ than baseline $27.3 \pm 6.4 \mathrm{cmH}_{2} \mathrm{O}$ Improvements: PEMax: $83 \pm 18.7 \mathrm{cmH}_{2} \mathrm{O}, \uparrow 38.3 \%$ than Cough with FES 
Table 3 Cross-over trials (Continued)

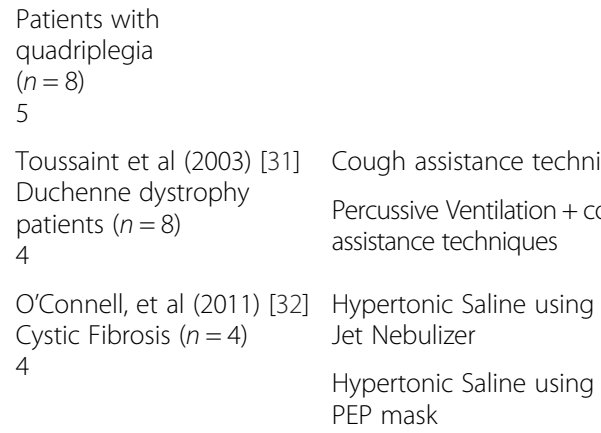

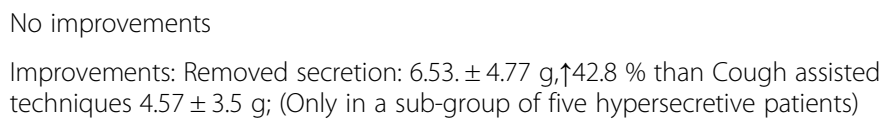

No improvements

Improvements: Subjective report of chest tightness $1.7 \mathrm{pts}, \downarrow 68 \%$ than without PEP mask 5.3pts

Values presented as mean \pm standard deviation or median (interquartile range). Insufflation-Exsufflation; MAC Manually assisted cough, NMD Neuromuscular Disease, ALS Amyotrophic lateral sclerosis, COPD Chronic obstructive pulmonary disease, SpO 2 Peripheral oxygen saturation, FVC Forced vital capacity, FEF25-75 \% Mean forced expiratory flow at 25-75\% expiratory period, WB Work of breath, FES Functional electrical stimulation, PEMax Maximum expiratory pressure, PEP Positive expiratory pressure. ${ }^{a}$ Results presented graphically in the original paper

patients present increased risk of pneumothorax, which might happen in patients with some cancers, such as sarcoma, lung carcinoma, germ cell tumor or lymphoma [47].

\section{Therapies to facilitate mucus clerance}

Before providing aid to promote expectoration, a therapist should perform some interventions to help the mucus collection from peripheral areas of the lung, to central airways, such as the trachea, where a cough or suctioning are able to remove the secretions from the airways.

Although chest physiotherapy is the most commonly used therapy, it was only present in studies as a control therapy; there were no studies that compared it to notreatment in patients in palliative care. Moreover, what was considered as chest physiotherapy was not the same in each study, and may have included manual vibration, postural drainage, manual or mechanical hypersinsuflation, chest compressions, PEP masks and suctioning. Nevertheless, two studies [17, 27] assessed the pre and post effects of chest physiotherapy (as a control therapy). They verified that chest physiotherapy was as effective as chest physiotherapy plus MIE, however the latter required more therapy time [27]. Moreover, chest physiotherapy improved arterial pressure of oxygen in $32 \%$ of participants, but the result was not statistically significant, probably due to the small sample size $(n=5)$ [17]. In addition, some evidence was found regarding other interventions with the same goal, such as PEP [20,32], vibratory vest [19], percussive ventilation [31]..

The therapy using PEP masks (Tables 2 and 3) improves mucus collection as it maintains the opening of peripheral airways during a forced expiration longer than without the device, which may influence the mucus clearance by increasing the period of expiratory flow. However, only one study was found in very severe COPD patients [20] and another in cystic fibrosis with very severe obstruction [32], which fitted palliative care criteria. In patients with COPD, this therapy may increase the discomfort caused by cough and dyspnoea while walking up a staircase (level 2) [20]. Nevertheless, in patients with cystic fibrosis, PEP masks associated with saline jet nebulizers improved the chest tightness subjective feeling when compared to only saline jet nebulisation (level 3) [32]. However, in the authors' opinion, since chest tightness is a less relevant outcome (an adverse effect of hypertonic saline nebulisation), the use of PEP mask are not recommended in both diseases until more evidence is found.

The therapy with oscillations or vibrations is based on the effects on increasing the mucociliary function, which mobilizes the secretions from peripheral airways and alter the mucus rheology [19]. Two ways to provide oscillations were found in the review, which were high frequency chest wall oscillations, commonly known as a vibratory vest (Table 2) and percussive ventilation (Table 3). The first method is a vest that inflates until the thorax is gently pressed. When the device is turned on, it inflates and deflates in a determined frequency (5$20 \mathrm{~Hz}$ ) that produces a vibration in the chest wall that is transferred to the airways and mucus. This method was assessed in amyotrophic lateral sclerosis (ALS) patients and failed to improve survival, rate of forced vital capacity (FVC) loss and the number of respiratory complications (level 3) [19]. However, some problems in the study, such as the difference in age between groups and the small sample ( $n=4$ in control group and $n=5$ in experimental group), are issues that prevent a better judgment in the use of the therapy. The percussive ventilation presented more promising results, resulting in a higher amount of secretion suctioned after the procedure, compared to usual care (level 3) [31]. Percussive ventilation is a therapy in which air pressure is provided by a device by a mask, endotracheal tube or tracheotomy and this pressure oscillates generating a vibration directly in the airways. 
Table 4 Evidence summary

\begin{tabular}{|c|c|c|c|c|c|c|c|c|c|c|c|c|}
\hline \multirow[t]{2}{*}{ Intervention } & \multirow[t]{2}{*}{ Disease } & \multicolumn{11}{|c|}{ Critically relevant for clinical decision } \\
\hline & & Comfort & Effectiveness & $\begin{array}{l}\text { Health related } \\
\text { quality of life }\end{array}$ & Survival & $\begin{array}{l}\text { Resting } \\
\text { dyspnoea }\end{array}$ & $\begin{array}{l}\text { Hospital } \\
\text { days }\end{array}$ & $\begin{array}{l}\text { Hospital } \\
\text { admission }\end{array}$ & $\begin{array}{l}\text { Intervention } \\
\text { duration }\end{array}$ & $\begin{array}{l}\text { Respiratory } \\
\text { complications }\end{array}$ & $\begin{array}{l}\text { Tracheotomy } \\
\text { prev/removal }\end{array}$ & Cough \\
\hline \multirow{3}{*}{$\begin{array}{l}\text { Mechanical } \\
\text { insufflator- } \\
\text { exsufflator }\end{array}$} & COPD & - & - & - & - & $\downarrow 3$ & - & - & - & - & - & - \\
\hline & $\mathrm{SCl}$ & - & - & - & - & - & - & $\leftrightarrow 3$ & - & $\leftrightarrow 3$ & - & - \\
\hline & NMD & $\uparrow 1^{\mathrm{a}}$ & $\uparrow 3$ & $\leftrightarrow 2$ & $\uparrow 2$ & $\downarrow 3$ & $\leftrightarrow 2$ & $\uparrow 2$ & $\downarrow 3$ & $\uparrow 2$ & $\uparrow 2$ & - \\
\hline EMT & MS & - & $\uparrow 2$ & - & - & - & - & - & - & - & - & - \\
\hline MAC & NMD & $\uparrow 3$ & $\uparrow 2$ & - & - & - & - & - & - & - & - & - \\
\hline \multirow[t]{2}{*}{ PEP Mask } & COPD & - & - & - & - & - & $\leftrightarrow 2$ & - & - & $\leftrightarrow 2$ & - & $\uparrow 2$ \\
\hline & CF & - & - & - & - & - & - & - & - & - & - & - \\
\hline FES & $\mathrm{SCl}$ & - & - & - & - & - & - & - & - & - & - & - \\
\hline $\begin{array}{l}\text { Percussive } \\
\text { ventilation }\end{array}$ & NMD & - & - & - & - & - & - & - & - & - & - & - \\
\hline $\begin{array}{l}\text { Vibratory } \\
\text { vest }\end{array}$ & NMD & - & - & - & $\leftrightarrow 3$ & - & - & - & - & $\leftrightarrow 3$ & - & - \\
\hline Tracheotomy & NMD & - & - & - & $\uparrow 2$ & - & - & - & - & - & - & - \\
\hline
\end{tabular}

Table 4 Evidence summary (Continued)

\begin{tabular}{|c|c|c|c|c|c|c|c|c|c|c|c|}
\hline \multirow[t]{2}{*}{ Intervention } & \multicolumn{6}{|c|}{ Relevant for Clinical Decision } & \multicolumn{5}{|c|}{ Less Relevant for Clinical Decision } \\
\hline & Oxygenation & $\begin{array}{l}\text { Dyspnoea during } \\
\text { exercise }\end{array}$ & PCF & FEV1 & FVC & $\begin{array}{l}\text { Secretion } \\
\text { Amount }\end{array}$ & $\mathrm{PaCO} 2, \mathrm{Ph}$ & Chest Tightness & Airway Resistance & PIMax & $\overline{\text { PEMax }}$ \\
\hline \multirow{3}{*}{$\begin{array}{l}\text { Mechanical } \\
\text { insufflator- } \\
\text { exsufflator }\end{array}$} & $\uparrow 3$ & - & $\leftrightarrow 3$ & - & - & - & - & - & - & - & - \\
\hline & $\leftrightarrow 3$ & - & $\uparrow 3$ & $\uparrow 3$ & $\uparrow 3$ & - & $\leftrightarrow 3$ & - & - & - & - \\
\hline & $\uparrow 3$ & - & $\uparrow 1^{\mathrm{a}}$ & - & $\uparrow 3$ & - & - & - & - & - & - \\
\hline EMT & - & - & - & - & - & - & - & - & - & $\uparrow 2$ & $\uparrow 2$ \\
\hline MAC & - & - & $\uparrow 2$ & - & - & - & - & - & - & - & $\uparrow 3$ \\
\hline \multirow[t]{2}{*}{ PEP Mask } & $\leftrightarrow 2$ & $\uparrow 2$ & - & $\leftrightarrow 2$ & $\leftrightarrow 2$ & $\leftrightarrow 2$ & $\uparrow 2$ & - & - & - & - \\
\hline & - & - & - & - & - & - & - & $\downarrow 3$ & - & - & - \\
\hline FES & - & - & - & - & - & - & - & - & - & - & $\uparrow 3$ \\
\hline $\begin{array}{l}\text { Percussive } \\
\text { ventilation }\end{array}$ & - & - & - & - & - & $\uparrow 2$ & - & - & $\leftrightarrow 2$ & - & - \\
\hline $\begin{array}{l}\text { Vibratory } \\
\text { vest }\end{array}$ & - & - & - & - & $\leftrightarrow 3$ & - & - & - & - & - & - \\
\hline Tracheotomy & - & - & - & - & - & - & - & - & - & - & - \\
\hline
\end{tabular}

\section{Therapies to improve cough efectiveness}

Some therapies are intended to help the individual to regain cough function, when this reaction is lost for some reason. Usually, it requires activating the expiratory muscles by an external stimulus [30] or increasing the expiratory muscle strength [18, 21]. When patients still have muscle mass, but are not able to activate it due to neurological impairment, such as spinal cord injury, functional electrical stimulation (FES) (Table 3) may help improve cough effectiveness by activating the abdominal muscles that were not functional [30]. One cross-over trial, with a small sample size, verified the use of FES in spinal cord injury and verified an increase in PEMax compared to control (level 3) [30]. However, more meaningful outcomes should be studied before suggesting the use of this therapy in palliative care patients, such as subjective impression of effectiveness, comfort during therapy, fatigue caused by the therapy and PCF.

Expiratory muscle training (Table 2) is largely used in respiratory physiotherapy [48] but only two studies [18, 21] were found in patients with very severe stages of the 
disease. Both studies verified expiratory muscle training on cough effectiveness in patients with multiple sclerosis with respiratory muscle impairment. The results of the studies regarding this training were conflicting. One study presented an increase in PEMax and no significant change in maximum inspiratory pressure (PIMax) [21], while the other study verified improvement in PIMax, subjective cough effectiveness assessment and FVC and no change in PEMax [18]. Nevertheless, expiratory muscle training might be a suitable therapy only in very specific situations in palliative care, since an adequate nutritional balance and a long-term adherence to the therapy are essential to a clinically significant strength improvement [49], which are not usually possible in this population.

\section{Discussion}

This paper systematically reviewed literature on interventions used to manage the presence of respiratory secretion. Nevertheless, there was limited evidence for most of the interventions and most were restricted to neurological and neuromuscular patients.

The low number of randomized controlled trials is similar to other reviews of symptom control in palliative care. Moreover, some interventions (such as tracheotomy) may be considered essential or usual care to patients despite the absence of evidence and therefore not providing this therapy to a group of patients in randomized controlled trial would be considered unethical.

The included randomized controlled trials and crossover trials had a low overall methodological quality. Although some methodological quality criteria are usually not achievable by non-pharmacological interventions, such as blinded therapists and patients, some criteria are possible to be met, which affects the trust in the results.

Although diseases in advanced stages, such as dementia and cancer, do often result in the occurrence of discomfort due to respiratory secretion, no studies regarding these diseases were found, probably due to the reduced number of studies focusing patients' comfort and symptom control in comparison to studies with therapies to control the advance of these diseases. There were only a limited number of studies on diseases where this condition is usually found [4], such as respiratory diseases. Neuromuscular diseases [45], such as Duchenne muscular dystrophy and amyotrophic lateral sclerosis, were more frequently studied.

Most therapies found in this review could be applied in palliative care situations, however more studies must be conducted to strengthen the evidence and broaden the populations that could be treated, especially in cancer. In addition, no studies were found which assessed drug therapy to relieve this symptom, which suggests that the use of anti-muscarinic drugs and mucolytics are based in studies that included patients with lower severity of the disease, or patients with death rattle.
More research is required for a better understanding of the efficacy of pharmacological and non-pharmacological therapies used in respiratory secretion management in patients in palliative care. The studies should be conducted with patients who may die in the following year, but are not so close to dying that respiratory secretion is considered to be treated only due to the sound it produces.

Additionally, none of the studies presented as the main outcome a patient-reported outcome measure (PROM), such as comfort and subjective effectiveness impression. These PROMs are critically relevant in authors' opinion, since they capture the preferences and impressions of the patient, which is essential when assessing a palliative intervention [50]. However, these PROMs were assessed as secondary outcomes to MAC and MIE interventions, and for both PROMs, they were considered acceptable by patients. Interventions to improve mucus clearance and to increase cough effectiveness were not assessed regarding subjective impression of effectiveness or comfort.

Therapies that most probably suited palliative care patients are MAC and MIE as they both promote expectoration, chest physiotherapy and percussive ventilation applied by non-invasive methods to improve mucus clearance. Therapies that simply improve voluntary cough effectiveness are less likely to be used in this context. Drug therapy, such as mucolytics and anti-muscarinic agents should also be studied to verify their short and long term effects. In addition studies that assess the subjective experience of treatment by patients are required.

\section{Study limitations}

Understandably this review has some limitations. Initially, the review was not prospectively registered. Moreover, a meta analysis was not done due to the large number of outcomes and therapies and the difference in methods among the studies would have affected this meta analysis; however, a broad overview of therapies which could be used in palliative care were identified, which can guide future steps in the research field. Moreover, the identification of studies that included patients who could be in a palliative care treatment were done using severity indices [51], such as forced expiratory volume in the first second in respiratory diseases and respiratory muscle impairment in neuromuscular and neurological diseases. Nevertheless this would be difficult to do, as few of the studies defined the population as palliative. Instead we included studies with patients suffering with an advanced disease akin to a palliative care population.

\section{Conclusion}

Therapies, such as MAC, MIE and percussive ventilation, which aim to deal with respiratory secretion, can be used 
in palliative care of specific diseases. Nevertheless, the evidence still needs to improve in order to identify which alternative is the best.

\section{Additional file}

Additional file 1: Table S1. Search Strategy, Table S2. PEDro Score in Randomized Controlled Trials, Table S3. PEDro Score in Cross-over Trials. (DOCX $18 \mathrm{~kb}$ )

\section{Abbreviations}

ALS, amyotrophic lateral sclerosis; CF, cystic fibrosis; COPD, chronic obstructive pulmonary disease; $E M T$, expiratory muscle training; $\mathrm{FEF}_{25-75 \%}$ mean forced expiratory flow at $25-75 \%$ expiratory period; FES, functional electrical estimulation; $\mathrm{FEV}_{1}$, forced expiratory volume in the first second; $\mathrm{FVC}$, forced vital capacity; MAC, manually-assisted cough; MIE, mechanical insufflation-exsufflation: MS, multiple sclerosis; NMD, neuromuscular disease; OCEBM, Oxford centre for evidence-based medicine; PCF, peak cough flow; PEMax, maximum expiratory pressure; PEP, positive expiratory pressure; PIMax, maximum inspiratory pressure; $\mathrm{PROM}$, patient-reported outcome measure; $\mathrm{SCl}$, spinal cord injury; $\mathrm{SpO}_{2}$, peripheral oxygen saturation; WB, work of breath

\section{Acknowledgments}

We are grateful for all the help provided by the colleagues in the International Observatory on End of Life Care (Lancaster University) and in the Spirometry and Respiratory Physiotherapy Laboratory (Federal University of São Carlos). Also we thanks the Coordenação de Aperfeiçoamento de Pessoal de Nível Superior (CAPES) for funding the research.

\section{Funding}

This study was funded by the Coordenação de Aperfeiçoamento de Pessoal de Nivel Superior (CAPES) Foundation, Ministry of Education, Brazil; through national and international scholarships provided to JFA (Process 3915/13-1).

\section{Availability of data and materials}

The datasets during and/or analysed during the current study available from the corresponding author on reasonable request.

\section{Authors' contribution}

JFA: conception and design of the study, acquisition of the data, analysis and interpretation of data, drafted the article and approved the final version. EA: acquisition of data, analysis and interpretation of data, drafted the article and approved the final version. NP: conception and design of the study, acquisition of data, analysis and interpretation, revised the article critically and approved the final version. JB: design of the study, acquisition of data, revised the article critically and approved the final version. VAPDL: conception and design of the study, acquisition of data, analysis and interpretation, revised the article critically and approved the final version.

\section{Competing interests}

JFA and VAPDL received equipments from Philips Respironics ${ }^{\oplus}$, which were loaned for the purpose of a subsequent research. Other authors do not have conflicts of interest.

\section{Consent for publication}

Not applicable.

\section{Ethics approval and consent to participate}

Not applicable.

\author{
Author details \\ ${ }^{1}$ Federal University of São Carlos, Rod Washington Luiz, km 235, Monjolinho, \\ São Carlos, SP CEP 13565-905, Brazil. ${ }^{2}$ International Observatory on End of \\ Life Care, Faculty of Health and Medicine, Furness College, Lancaster \\ University, Bailrigg LA1 4YG, UK. ${ }^{3}$ Lancaster University Library, Lancaster \\ University, Bailrigg LA1 4YG, UK.
}

Received: 11 February 2016 Accepted: 1 August 2016

Published online: 09 August 2016

\section{References}

1. Elman LB, Dubin RM, Kelley M, McCluskey L. Management of oropharyngeal and tracheobronchial secretions in patients with neurologic disease. J Palliat Med. 2005;8(6):1150-9.

2. Vitacca M, Comini L. How do patients die in a rehabilitative unit dedicated to advanced respiratory diseases? Multidiscip Respir Med. 2012;7(1):18.

3. Kim WD. Lung mucus: a clinician's view. Eur Respir J. 1997;10(8):1914-7.

4. Rogers DF. Physiology of airway mucus secretion and pathophysiology of hypersecretion. Respir Care. 2007;52(9):1134-46. discussion 1146-1139.

5. Sekizawa K, Ujiie Y, Itabashi S, Sasaki H, Takishima T. Lack of cough reflex in aspiration pneumonia. Lancet. 1990;335(8699):1228-9.

6. Perrin C, Unterborn JN, Ambrosio CD, Hill NS. Pulmonary complications of chronic neuromuscular diseases and their management. Muscle Nerve. 2004;29(1):5-27.

7. Nakajoh K, Nakagawa T, Sekizawa K, Matsui T, Arai H, Sasaki H. Relation between incidence of pneumonia and protective reflexes in post-stroke patients with oral or tube feeding. J Intern Med. 2000;247(1):39-42.

8. AARC AAfRC. AARC clinical practice guideline. Nasotracheal suctioning. Respir Care. 1992;37(8):898-901.

9. ANCP ANdCP. Manual de cuidados paliativos ANCP. 2nd ed. 2012

10. Conselho Regional de Medicina do Estado de São Paulo CREMESP: Cuidado Paliativo. São Paulo; 2008.

11. Poole P, Black PN. Mucolytic agents for chronic bronchitis or chronic obstructive pulmonary disease. Cochrane Database Syst Rev. 2010;2:CD001287.

12. van der Schans CP. Conventional chest physical therapy for obstructive lung disease. Respir Care. 2007;52(9):1198-206. discussion 1206-1199.

13. Osadnik CR, McDonald CF, Jones AP, Holland AE. Airway clearance techniques for chronic obstructive pulmonary disease. Cochrane Database Syst Rev. 2012; 3:CD008328.

14. Shiwa SR, Costa LO, Costa Lda C, Moseley A, Hespanhol Junior LC, Venancio R, Ruggero C, Sato Tde O, Lopes AD. Reproducibility of the Portuguese version of the PEDro Scale. Cad Saude Publica. 2011;27(10):2063-8.

15. Maher CG, Sherrington C, Herbert RD, Moseley AM, Elkins M. Reliability of the PEDro scale for rating quality of randomized controlled trials. Phys Ther. 2003;83(8):713-21.

16. Group OLoEW. The Oxford 2011 levels of evidence. In: Oxford centre for evidence-based medicine. 2011.

17. Pillastrini P, Bordini S, Bazzocchi G, Belloni G, Menarini M. Study of the effectiveness of bronchial clearance in subjects with upper spinal cord injuries: examination of a rehabilitation programme involving mechanical insufflation and exsufflation. Spinal Cord. 2006;44(10):614-6.

18. Gosselink R, Kovacs L, Ketelaer P, Carton H, Decramer M. Respiratory muscle weakness and respiratory muscle training in severely disabled multiple sclerosis patients. Arch Physical Med Rehabil. 2000;81(6):747-51.

19. Chaisson KM, Walsh S, Simmons Z, Vender RL. A clinical pilot study: high frequency chest wall oscillation airway clearance in patients with amyotrophic lateral sclerosis. Amyotroph Lateral Scler. 2006;7(2):107-11.

20. Christensen HR, Simonsen K, Lange P, Clementsen P, Kampmann JP, Viskum K, Heideby J, Koch U. PEEP-masks in patients with severe obstructive pulmonary disease: a negative report. Eur Respir J. 1990;3(3):267-72.

21. Smeltzer SC, Lavietes MH, Cook SD. Expiratory training in multiple sclerosis. Arch Phys Med Rehabil. 1996;77(9):909-12

22. Rafiq MK, Bradburn M, Proctor AR, Billings CG, Bianchi S, McDermott CJ, Shaw PJ. A preliminary randomized trial of the mechanical insufflator-exsufflator versus breath-stacking technique in patients with amyotrophic lateral sclerosis. Amyotroph Lateral Scler Frontotemporal Degener. 2015;16(7-8):448-55.

23. Senent C, Golmard J-L, Salachas F, Chiner E, Morelot-Panzini C, Meninger V, Lamouroux C, Similowski T, Gonzalez-Bermejo J. A comparison of assisted cough techniques in stable patients with severe respiratory insufficiency due to amyotrophic lateral sclerosis. Amyotroph Lateral Scler. 2011;12(1):26-32.

24. Winck JC, Gonçalves MR, Lourenço C, Viana P, Almeida J, Bach JR. Effects of mechanical insufflation-exsufflation on respiratory parameters for patients with chronic airway secretion encumbrance. Chest. 2004;126(3):774-80.

25. Bach JR. Mechanical insufflation-exsufflation. Comparison of peak expiratory flows with manually assisted and unassisted coughing techniques. Chest. 1993;104(5):1553-62.

26. Sancho J, Servera E, Vergara P, Marin J. Mechanical insufflation-exsufflation vs. tracheal suctioning via tracheostomy tubes for patients with amyotrophic lateral sclerosis: a pilot study. Am J Phys Med Rehabil. 2003:82(10):750-3.

27. Chatwin M, Simonds AK. The addition of mechanical insufflation/exsufflation shortens airway-clearance sessions in neuromuscular patients with chest infection. Respir Care. 2009;54(11):1473-9. 
28. Chatwin M, Ross E, Hart N, Nickol AH, Polkey Ml, Simonds AK. Cough augmentation with mechanical insufflation/exsufflation in patients with neuromuscular weakness. Eur Respir J. 2003;21(3):502-8.

29. Lacombe M, Del Amo CL, Bore A, Chapeau D, Horvat E, Vaugier I, Lejaille M, Orlikowski D, Prigent H, Lofaso F. Comparison of three cough-augmentation techniques in neuromuscular patients: mechanical insufflation combined with manually assisted cough, insufflation-exsufflation alone and insufflation-exsufflation combined with manually assisted cough. Respiration. 2014;88(3):215-22.

30. Linder SH. Functional electrical stimulation to enhance cough in quadriplegia. Chest. 1993;103(1):166-9.

31. Toussaint M, De Win H, Steens M, Soudon P. Effect of intrapulmonary percussive ventilation on mucus clearance in duchenne muscular dystrophy patients: a preliminary report. Respir Care. 2003;48(10):940-7.

32. O'Connell OJ, O'Farrell C, Harrison MJ, Eustace JA, Henry MT, Plant BJ. Nebulized hypertonic saline via positive expiratory pressure versus via jet nebulizer in patients with severe cystic fibrosis. Respir Care. 2011;56(6):771-5.

33. Bach JR. Amyotrophic lateral sclerosis - prolongation of life by noninvasive respiratory aids. Chest. 2002;122(1):92-8.

34. Bach JR, Martinez D. Duchenne muscular dystrophy: continuous noninvasive ventilatory support prolongs survival. Respir Care. 2011;56(6):744-50.

35. Bach JR, Saporito $L R$, Shah $H R$, Sinquee D. Decanulation of patients with severe respiratory muscle insufficiency: efficacy of mechanical insufflation-exsufflation. J Rehabil Med. 2014;46(10):1037-41.

36. Bento J, Goncalves M, Silva N, Pinto T, Marinho A, Winck JC. Indications and compliance of home mechanical insufflation-exsufflation in patients with neuromuscular diseases. Archivos De Bronconeumología. 2010;46(8):420-5.

37. Crew JD, Svircev JN, Burns SP. Mechanical insufflation-exsufflation device prescription for outpatients with tetraplegia. J Spinal Cord Med. 2010;33(2):128-34.

38. Gomez-Merino E, Bach JR. Duchenne muscular dystrophy: prolongation of life by noninvasive ventilation and mechanically assisted coughing. Am J Physical Med Rehabil. 2002;81(6):411-5.

39. Ishikawa Y, Miura T, Aoyagi T, Ogata H, Hamada S, Minami R. Duchenne muscular dystrophy: survival by cardio-respiratory interventions. Neuromuscul Disord. 2011:21(1):47-51.

40. Sancho J, Servera E, Díaz JL, Bañuls P, Marín J. Home tracheotomy mechanical ventilation in patients with amyotrophic lateral sclerosis: causes, complications and 1-year survival. Thorax. 2011;66(11):948-52.

41. Servera E, Sancho J, Zafra MJ, Catalá A, Vergara P, Marín J. Alternatives to endotracheal intubation for patients with neuromuscular diseases. Am J Phys Med Rehabil. 2005;84(11):851-7.

42. Soudon P, Steens M, Toussaint M. A comparison of invasive versus noninvasive full-time mechanical ventilation in Duchenne muscular dystrophy. Chron Respir Dis. 2008:5(2):87-93.

43. Vianello A, Corrado A, Arcaro G, Gallan F, Ori C, Minuzzo M, Bevilacqua M. Mechanical insufflation-exsufflation improves outcomes for neuromuscular disease patients with respiratory tract infections. Am J Phys Med Rehabil. 2005;84(2):83-8. discussion 89-91.

44. Siewers V, Holmoy T, Frich JC. Experiences with using mechanical in-exsufflation in amyotrophic lateral sclerosis. Eur J Physiother. 2013:15:201-7.

45. Boitano L. Management of airway clearance in neuromuscular disease. Respir Care. 2006;51(8):913-22. discussion 922-914.

46. Morrow $B$, Zampoli $M$, van Aswegen $H$, Argent A. Mechanical insufflationexsufflation for people with neuromuscular disorders. Cochrane Database Syst Rev. 2013;12:CD010044.

47. Somasekharan Nair KK, Zabell AS, Vo KL, Shaikh MA. Pneumothorax: a classical presentation of metastatic scalp angiosarcoma. Ann Thorac Surg. 2012;94(3): e77-78.

48. Neves LF, Reis MH, Plentz RD, Matte DL, Coronel CC, Sbruzzi G. Expiratory and expiratory plus inspiratory muscle training improves respiratory muscle strength in subjects with COPD: systematic review. Respir Care. 2014:59(9):1381-8.

49. Atherton PJ, Smith K. Muscle protein synthesis in response to nutrition and exercise. J Physiol. 2012;590(Pt 5):1049-57.

50. Evans CJ, Benalia H, Preston NJ, Grande G, Gysels M, Short V, Daveson BA, Bausewein C, Todd C, Higginson IJ, et al. The selection and use of outcome measures in palliative and end-of-life care research: the MORECare international consensus workshop. J Pain Symptom Manage. 2013;46(6):925-37.

51. Stuart B. The NHO medical guidelines for Non-cancer disease and local medical review policy: hospice access for patients with diseases other than cancer. Hosp J. 1999;14(3-4):139-54.

\section{Submit your next manuscript to BioMed Central and we will help you at every step:}

- We accept pre-submission inquiries

- Our selector tool helps you to find the most relevant journal

- We provide round the clock customer support

- Convenient online submission

- Thorough peer review

- Inclusion in PubMed and all major indexing services

- Maximum visibility for your research

Submit your manuscript at www.biomedcentral.com/submit
Biomed Central 